\title{
Eksplorasi Etnomatematika Pada Permainan Tradisional Indonesia Komunitas TGR (Traditional Games Return)
}

\author{
Citra Demi Karina ${ }^{1}$, Supardi U.S ${ }^{2}$, Suparman, I.A ${ }^{3}$ \\ 1, 2, 3 Prodi Magister Pendidikan Matematika dan Ilmu Pengetahuan Alam, Fakultas Pascasarjana, Universitas Indraprasta PGRI, \\ Jl. Nangka No 58C, (TB Simatupang), Kel. Tanjung Barat, Kec. Jagakarsa, Jakarta Selatan, Indonesia \\ demikarina17@gmail.com
}

\begin{abstract}
The purpose of this study was to determine content of the elements of mathematics in catfish stakes games, marbles games, congklak games, giant snake ladder games, kite games, moonlight games, and bekel games. Research method used is ethnographic method with ethnomatematics specifications. Data collection used is by conducting in-depth interviews, documentary methods and observation. From results of the analysis obtained conclusions, the explanation is as follows: (1) Traditional game of catfish stakes contains elements of unit length, recognizes building tube space, and calculating scores addition, multiplication, substraction and division operations. (2) Traditional gundu games contain elements of building a spherical space, building a flat circle, reducing operations, and making a circle pattern. (3) Traditional congklak games contain elements of counting operations and sequence numbers. (4) The traditional giant snake ladder game contains elements of numbers, counting operations and opportunities. (5) Traditional kite games contain elements of flat kite building. (6) Traditional games in the moon contain elements of pattern making, building a square flat, rectangular and semicircle, and counting operations. (7) Traditional bekel games contain elements of ball space and counting operations. Elements in the traditional game can be used as educational media for mathematics learning and prove that mathematics can be learned in fun way.
\end{abstract}

Keywords: Ethnomatematics; Traditional Games; Traditional Games Returns Community

\begin{abstract}
Abstrak
Tujuan penelitian ini untuk mengetahui kandungan unsur matematika pada permainan patok lele, permainan gundu, permainan congklak, permainan ular tangga raksasa, permainan layangan, permainan dampu bulan, dan permainan bekel. Metode penelitian yang digunakan adalah metode etnografi dengan spesifikasi etnomatematika. Pengumpulan data yang digunakan adalah dengan melakukan wawancara mendalam, metode dokumenter dan metode observasi atau pengamatan. Dari hasil analisis diperoleh simpulan, penjelasannya sebagai berikut: (1) Permainan tradisional patok lele mengandung unsur satuan panjang, mengenal bangun ruang tabung, dan menghitung skor mencakup operasi penjumlahan, perkalian, pengurangan dan pembagian. (2) Permainan tradisional gundu mengandung unsur bangun ruang bola, bangun datar lingkaran, operasi pengurangan, dan membuat pola lingkaran. (3) Permainan tradisional congklak mengandung unsur operasi hitung dan urutan bilangan. (4) Permainan tradisional ular tangga raksasa mengandung unsur bilangan, operasi hitung dan peluang. (5) Permainan tradisional layangan mengandung unsur bangun datar layang-layang. (6) Permainan tardisional dampu bulan mengandung unsur membuat pola, bangun datar persegi, persegi panjang dan setengah lingkaran, dan operasi hitung. (7) Permainan tradisional bekel mengandung unsur bngun ruang bola dan operasi hitung. Unsur-unsur pada permainan tradisional tersebut dapat digunakan sebagai media edukasi pembelajaran matematika dan membuktikan bahwa matematika bisa dipelajari dengan cara menyenangkan.
\end{abstract}

Kata kunci: Etnomatematika, Permainan Tradisional, Komunitas Traditional Games Returns

Copyright (c) 2021 Citra Demi Karina, Supardi U.S., Suparman, I.A

$\triangle$ Corresponding author: Citra Demi Karina

Email Address: demikarina17@ gmail.com (Jl. Nangka No 58C, (TB Simatupang), Kel. Tanjung Barat)

Received 08 Juni 2021, Accepted 15 Juni 2021, Published 17 Juni 2021

\section{PENDAHULUAN}

Pada zaman saat ini jarang ditemui masyarakat bermain permainan tradisional seperti permainan patok lele, permainan bekel, permainan gobak sodor, dan sebagainya. Hilangnya permainan tradisional anak selain akibat pengaruh globalisasi juga diakibatkan oleh beberapa faktor yaitu faktor historis, faktor kebijaksanaan dalam pendidikan formal, faktor hilangnya prasarana, serta terdesaknya permainan tradisional dengan permainan impor yang lebih modern. Orang dewasa tidak lagi mengenalkan permainan 
tradisional kepada generasinya, lahan yang kosong semakin jarang, tidak adanya material permainan tradisional dalam kurikulum, serta gempuran permainan modern seperti playstation, game online dan sejenisnya. Tak dapat dipungkiri anak-anak menghabiskan waktu berjam-jam untuk bermain permainan modern tersebut, yang tentunya menghabiskan uang yang tidak sedikit. Senada dengan pendapat (Mulyani, 2016) mengatakan ketika anak bermain game online, playstation, atau video games dalam waktu relatif wajar, bukanlah masalah. Namun, bila anak sudah kecanduan dengan permainan modern ini, dan ia bisa menghabiskan waktu berjam-jam, tentunya ini bukan persoalan sederhana.

Dari hal ini, suatu komunitas permainan tradisional yaitu Komunitas Traditional Games Return (TGR) berupaya agar permainan tradisional tetap lestari kembali dengan berbagai program yang mereka jalankan, misalnya Aksi TGR, TGR Jalan-jalan, Info TGR. Kegiatannya dilakukan secara online melalui akun @tgrcampaign ataupun offline. Kini kampanyenya telah tersebar di 22 provinsi melalui para ambasador TGR yang berjumlah 73 orang dari perwakilan tiap daerah, yang bergerak secara bersama mengampanyekan permainan tradisional. Berbicara soal perhatian komunitas terhadap permainan tradisional bahwa hampir hilangnya berbagai jenis permainan tradisional yang ada di Indonesia. Peran orang tua, pendidik, atau calon pendidik hendaknya bisa lebih memerhatikan kelestarian kembali permainan tradisional untuk dapat dijadikan media atau wahana dalam mengembangkan aspek-aspek perkembangan dasar anak. Menurut Subagiyo dalam (Mulyani, 2016) salah satu manfaat anak-anak bermain permainan tradisional adalah dapat mengembangkan kecerdasan logika anak. Dalam hal ini permainan tradisional tidak hanya mengandung unsur kesenangan saja, tetapi juga mengandung nilai-nilai budaya dan dapat melatih kecakapan berpikir serta berhitung. Permainan tradisional memiliki nilai-nilai akan konsep matematika dimana jika anak memainkannya, maka secara tidak langsung mereka sedang mempelajari matematika.

Memperbaiki pendidikan tentu menjadi modal utama dalam upaya peningkatan kesejahteraan bangsa. Untuk itu kita perlu menggali, melestarikan dan mengembangkan kebudayaan Indoensia. Salah satunya adalah dengan etnomatematika permainan tradisional dimana bahwasanya konsep matematika lahir bersama masyarakat. Etnomatematika adalah penggunaan nilai-nilai matematika dalam suatu kebudayaan atau adat-istiadat yang ada pada suatu masyarakat. Adapun penggunaan etnomatematika seperti pada permainan tradisional, terlihat dari bagaimana cara memainkannya dan filosofi yang ada pada permainan tradisional itu sendiri. (Dharmamulya, 2008) mengungkapkan bahwa pada permainan tradisional mengandung nilai-nilai budaya seperti nilai kesenangan atau kegembiraan, nilai kebebasan, nilai demokrasi, nilai kepemimpinan, nilai dapat melatih kecakapan dalam berhitung, melatih kecakapan dalam berpikir dan berlogika, menumbuhkan rasa tanggung jawab dan rasa berteman.

Oleh karena itu, peneliti mengambil peran dalam menelaah etnomatematika pada permainan tradisional Indonesia yang dimainkan oleh Komunitas TGR. Adapun rumusan permasalahan yang dikemukakan peneliti adalah, "Bagaimana unsur matematika pada permainan patok lele, gundu, congklak, ular tangga, layangan, dampu bulan, dan bekel?" Harapannya dari hasil penelitian ini dapat dimanfaatkan sebagai referensi dalam pembuatan desain media pembelajaran matematika, sebagai gagasan baru dalam kurikulum sekolah, dan juga siswa kenal dengan nilai-nilai budaya yang dapat membentuk karakter. 


\section{METODE}

Berdasarkan permasalahan yang diangkat dalam penelitian ini maka pendekatan yang tepat digunakan untuk penelitian ini adalah penelitian kualitatif. Penelitian kualitatif sering disebut metode penelitian naturalistik karena penelitiannya dilakukan pada kondisi yang alamiah (Sugiyono, 2008). Penelitian ini menggunakan metode etnografi dengan spesifikasi etnomatematika. Etnografi adalah menyelidiki tentang budaya masyarakat dilingkungan alamiahnya (Ghony \& Almanshur, 2014). Pendekatan etnografis secara umum adalah pengamatan, berperan serta sebagai bagian dari penelitian lapangan. Adapun etnomatematika adalah suatu ilmu yang digunakan untuk memahami bagaimana matematika diadaptasi dari sebuah budaya. Penggunaan matematika dari suatu kelompok budaya dan dapat dianggap sebagai studi tentang diidentifikasinya ide-ide matematika yang ditemukan pada setiap budaya. Tujuan dari penelitian ini adalah mengetahui unsur-unsur matematika pada permainan tradisional Indonesia yang disosialisasikan oleh Komunitas TGR.

Penelitian ini menggunakan jenis deskriptif eksploratif. Penelitian eksploratif adalah jenis penelitian yang bertujuan untuk menggambarkan keadaan suatu fenomena. Dalam penelitian ini tidak dimaksudkan untuk menguji hipotesis tertentu, tetapi hanya menggambarkan apa adanya suatu variabel, gejala atau keadaan (Arikunto, 2002). Pengumpulan data yang digunakan dalam penelitian ini dengan melakukan wawancara mendalam, metode dokumenter dan metode observasi atau pengamatan.

Penelitian ini dilaksanakan dengan masa mulai bulan Oktober sampai dengan bulan Desember 2018. Subjek penelitian adalah anggota Komunitas TGR, yang mana memiliki karakterisik yakni menggalakan permainan tradisional Indonesia, sehingga relatif representatif untuk menggali data pada komunitas tersebut. Adapun desain penelitian yang digunakan peneliti merujuk pada Siklus Penelitian Etnografi Spradley (Emzir, 2012) sebagai berikut:

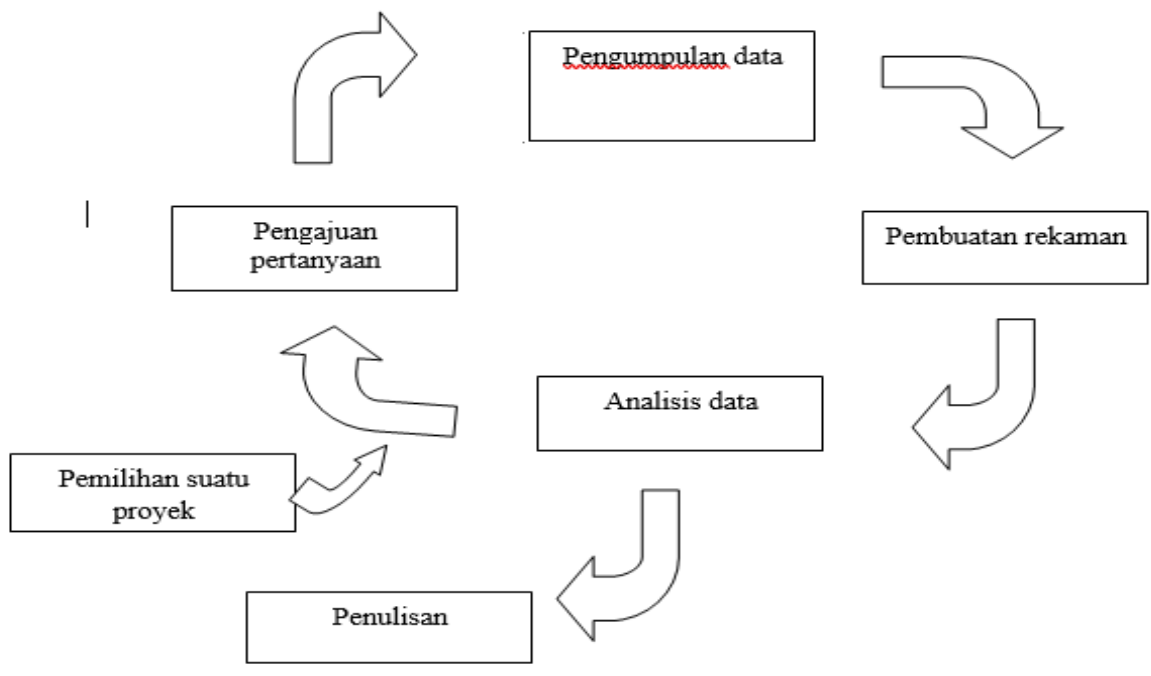

Gambar 1. Siklus Penelitian Etnografi Spradley

Berdasarkan gambar di atas, maka langkah penelitian dapat dideskripsikan melalui tabel berikut: 
Tabel 2. Deskripsi langkah Penelitian

\begin{tabular}{|c|l|l|}
\hline No & \multicolumn{1}{|c|}{ Tahap Penelitian } & \multicolumn{1}{|c|}{ Deskripsi } \\
\hline 1 & Pemilihan suatu proyek & $\begin{array}{l}\text { Etnomatematika pada permainan tradisional Indonesia } \\
\text { pada komunitas TGR }\end{array}$ \\
\hline 2 & Pengajuan pertanyaan & $\begin{array}{l}\text { Penyusunan daftar ajuan pertanyaan, seperti contoh } \\
\text { bagaimana filosofi dari permainan tradisional ini, dan } \\
\text { adakah unsur matematika dari permainan tradisional } \\
\text { tersebut? }\end{array}$ \\
\hline 3 & Pengumpulan data & $\begin{array}{l}\text { Wawancara mendalam, metode dokumenter dan metode } \\
\text { observasi atau pengamatan menjadi pedoman dalam } \\
\text { pengumpulan data. } \\
\text { Peneliti juga menelusuri data historis dan mengungkapkan } \\
\text { konsep matematika dengan fokus pada 7 jenis permainan } \\
\text { yang dimainkan komunitas TGR, antara lain Patok Lele, } \\
\text { Gundu, Congklak, Ular Tangga, Layangan, Dampu Bulan, } \\
\text { dan Bekel. }\end{array}$ \\
\hline 4 & Pembuatan rekaman & $\begin{array}{l}\text { Menghimpun data berdasarkan hasil wawancara, } \\
\text { dokumenter, dan hasil observasi }\end{array}$ \\
\hline 5 & Analisis data & $\begin{array}{l}\text { Pelaksanaan uji credibility atau validitas internal, dapat } \\
\text { berupa triangulasi sumber, yakni membandingkan data } \\
\text { hasil observasi dengan hasil wawancara, membandingkan } \\
\text { penjelasan dari komunitas TGR dengan persepsi personal, } \\
\text { dan membandingkan hasil wawancara dengan dokumen- } \\
\text { dokumen terkait. } \\
\text { Selain itu, dengan melaksanakan validitas eksternal, yakni } \\
\text { pengecekan yang dapat dilakukan oleh rekan peneliti, } \\
\text { pembimbing, atau promotor atas hasil pelaksanaan } \\
\text { wawancara, dokumenter, dan observasi. }\end{array}$ \\
\hline 6 & Penulisan & $\begin{array}{l}\text { Penyusunan laporan dengan merujuk pada hasil penelitian } \\
\text { yang relevan }\end{array}$ \\
\hline
\end{tabular}

\section{HASIL DAN DISKUSI}

\section{Hasil}

\section{Deskripsi Budaya Komunitas TGR}

Komunitas TGR merupakan komunitas yang terdiri dari anak muda yang berasal dari berbagai daerah. Saat ini komunitas TGR beranggotakan 52 orang dengan memiliki tujuan yang sama yaitu mengembalikan eksistensi permainan tradisional. Dengan pemahaman yang sejalan, maka kebudayaan yang tampak dari masing-masing anggota dapat berjalan. Komunitas TGR memainkan permainan tradisional setiap akan menyelenggarakan kegiatan di suatu tempat. Tentu banyak hal yang harus dipersiapkan oleh para anggota ketika kegiatan ini akan dilakukan. Setiap permainan memiliki keunikan tersendiri dan hal ini menjadi daya tarik bagi anak-anak. Dari sekian banyak permainan tradisional yang ada di Indonesia, adapun permainan yang sudah menjadi inventaris Komunitas TGR adalah sebagai berikut.

Tabel 2. Daftar Nama Permainan Tradisional

\begin{tabular}{|l|l|c|l|c|l|}
\hline \multicolumn{5}{|c|}{ Nama Permainan Tradisional } \\
\hline 1 & Bakiak & 11 & Keprayan & 21 & Panggal Kecil \\
\hline 2 & Balap Karung & 12 & Kincir Angin Wayang & 22 & Patok Lele \\
\hline
\end{tabular}




\begin{tabular}{|c|l|c|l|c|l|}
\hline \multicolumn{9}{|c|}{ Nama Permainan Tradisional } \\
\hline 3 & Bola Bekel & 13 & Klotokan & 23 & Perahu Itok-Otok \\
\hline 4 & Boy-Boyan & 14 & Kuda Lumping & 24 & Pesawat Kayu \\
\hline 5 & Congklak & 15 & Layangan & 25 & Pletokan \\
\hline 6 & Dampu Bulan & 16 & Lenggang Rotan & 26 & Priwitan Bambu Double \\
\hline 7 & Egrang Bambu & 17 & Lompat Karet & 27 & Priwitan Bambu Single \\
\hline 8 & Egrang Batok & 18 & Marakas & 28 & Rangku Alu \\
\hline 9 & Gambang & 19 & Masak-Masakan & 29 & Suling Bambu \\
\hline 10 & Gundu & 20 & Mobil-Mobilan & 30 & Ular Tangga Raksasa \\
\hline
\end{tabular}

Sumber: Arsip Komunitas TGR

\section{Deskripsi Permainan Tradisional}

Permainan yang dimainkan oleh Komunitas TGR sebagaimana penjelasan pada tabel di atas merupakan jenis permainan tradisional yang masih dimainkan oleh masyarakat, dan juga alat permainannya pun mudah ditemukan. Beberapa diantaranya ada yang dibuat khusus oleh komunitas TGR dan sebagian lainnya dibeli dari beberapa tempat. Di saat kunjungan ke suatu daerah, komunitas ini pun menyempatkan waktu untuk mencari permainan tradisional yang khusus dimainkan oleh daerah tersebut.

\section{Permainan Patok Lele}

Peralatan yang digunakan 2 potong kayu dengan diameter $3 \mathrm{~cm}$, yang mana panjang induk atau pemukul 1 potong kayu dengan panjang $15 \mathrm{~cm}$, dan anak patok lele dengan panjang $45 \mathrm{~cm}$. Pada tahap awal pemain menyiapkan lubang oval di tanah dan garis start kurang lebih 1,5 m lalu bersuit untuk menentukan siapa yang main terlebih dahulu misalnya regu A senagai pemain dan regu B sebagai penjaga. Langkah selanjutnya sebagai berikut: Tahap pertama, anak patok lele diletakkan melintang pada lubang dengan posisi membentuk 45 derajat. Kemudian diangkat dan dilemparkan ke depan kuat-kuat. Lawan bersiap menjaga di depan. Apabila anak patok lele dapat ditangkap, maka pemain akan berganti. Nilai yang didapat oleh B bila berhasil menangkap 1 tangan adalah 10, dan bila dengan 2 tangan adalah 5. Apabila B tidak berhasil menangkap anak patok lele tersebut, maka A masih tetap bermain dengan meletakkan anak patok lele pada lubang, kemudian B melempar patok lele tersebut dengan induk patok lele. Bila lemparan B berhasil maka A dinyatakan mati, dan selanjutnya B yang mengambil alih permainan. Tahap kedua, pemain harus berdiri dibelakang garis, induk patok lele memukul anak patok lele dengan melambungkannya ke udara.

Tahap ketiga, induk lele dilemparkan oleh lawan ke arah anak patok lele apabila terkena maka mendapatkan poin. Tahap keempat, anak patok lele diletakkan kembali ke dalam lubang dengan posisi tertidur kemudian diungkit dengan induk patok lele sampai memantul ke atas lalu dipukul horizontal sejauh mungkin. Apabila pemukul dapat melakukan pukulan sempurna maka nilai dikalikan dua kali lipat. Tapi jika anak patok lele tertangkap lawan maka semua nilai yang dihasilkan diambil alih oleh lawan. Tahap kelima, nilai dihitung menurut jarak antara anak patok lele yang jatuh dengan lubang awal menggunakan induk patok lele. 


\section{Permainan Gundu}

Permainan ini populer sejak zaman penjajahan Belanda dan dapat dimainkan setiap saat serta dimainkan seluruh kelompok sosial masyarakat. memiliki banyak nama seperti Nekeran (Jawa Timur), Kendeker (NTB), Palogan Gundu (DKI Jakarta) dan Modaka (Sulawesi Utara). Pemain minimal 2 orang, peralatannya berupa gundu yang terbuat dari kaca, tanah liat, marmer atau porselin.

Langkah-langkah dalam memainkan permainan gundu adalah sebagai berikut.

a. Pemain membuat batas dengan garis antara jarak pemain dengan gundu yang dibidik. gundu terdapat dalam dua lingkaran

b. Pemain menyepakati jumlah gundu yang akan dimasukkan ke dalam lingkaran.

c. Melempar gundu secara bergiliran.

d. Gundu yang lebih dekat dengan lingkaran paling luar adalah gundu yang harus dimainkan pertama. Gundu yang pertama dimainkan harus bisa mengusir gundu bidikan.

e. Jika pemain berhasil mengeluarkan gundu dari lingkaran, maka menjadi hak milik.

f. Pemenang ditentukan dari bamyaknya jumlah gundu yang diperoleh.

\section{Permainan Congklak}

Congklak merupakan permainan tradisional yang digemari masyarakat dan menyebar hampir di seluruh wilayah Indonesia. Nama congklak sendiri berasal dari bahasa Indonesia. Dalam memainkan congklak membutuhkan papan congklak dan buah congklak. Papan congklak dapat terbuat dari plastik, kayu polos, kayu bercorak warna-warni, atau kayu lipat corak berwarna-warni. Sementara buah congklak dapat terbuat dari batu-batu kecil, kulit remis, kulit sipit, buah segorok, keong laut yg sudah mati, dan sebagianya.

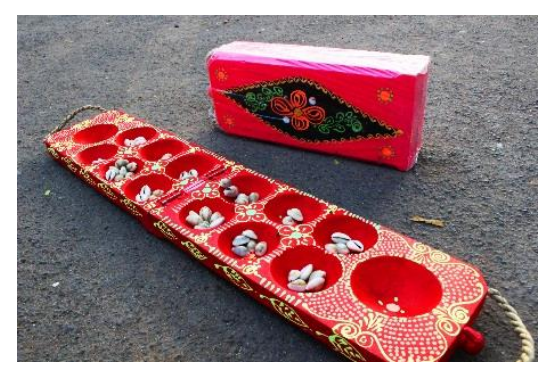

Gambar 2. Alat Permainan Congklak (Sumber: Dokumentasi TGR Store)

Jalannya permaian congklak sebagai berikut:

a. Dengan cara bersamaan kedua pemain mengambil buah dari salah satu lubang dan mengisi satu persatu ke lubang lainnya kea rah kanan atau searah jarum jarum jam mengisi rumah masing-masing kalau masih sisa di tangan maka diteruskan ke lubang lawan.

b. Bila buah dalam tangan habis, maka semua isi lubang dari buah terakhir diambil dan dibagikan lagi satu persatu ke lubang berikutnya

c. Bila buah terakhir sampai ke rumah sendiri, permainan masih dapat terus berjalan dengan mengambil buah dari salah satu anak lubang sendiri. Bila buah terakhir sampai di tempat kosong di anak lubang kita sendiri, maka kita boleh mengambil semua buah pada lubang yang berhadapan dengan lubang 
kosong tadi yang disebut dengan istilah menembak. Akan tetapi bila buah terakhir kita sampai ke lubang kosong lawan maka kita tidak dapat meneruskan permainan atau disebut mati maka permainan dilakukan oleh pihak lawan

d. Lawan dapat menjalankan buahnya, dan bila bertemu dengan lubang lawan kosong berarti mati. Demikian seterusnya sampai buah habis dan setiap emain berusaha mengisi rumahnya sebanyak mungkin.

e. Bila buah pada anak lubang sudah terisi sebanyak 7 buah dan di rumah masih banyak sisa maka kita dinamakan menang tekek. Dan biasanya yang kalah tidak cukup lagi buahnya untuk mengisi setiap lubang 7 buah, keadaan lubang yang kosong disebut terpanggang.

f. Sisa buah tidak dapat dimasukkan ke anak lubang, tetapi tetap pada lubang rumah. Misalnya pada lubang yang terpanggang ada 4 buah, maka di lubang rumah kita harus ada 3 buah yang mendapat giliran main terlebih dahulu adalah buahnya masih tersisa pada anak lubang. Biasanya pemain yang lubangnya terpanggang makin lama bermain makin banyak lubangnya yang kosong, namun kalau dia terampil lubangnya yang kosong, namun kalau dia terampil lubangnya dapat terisi kembali.

\section{Permainan Ular Tangga}

Ular tangga adalah permainan papan yang dimainkan minimal 2 orang. Namun dalam hal ini Komunitas TGR melakukan inovasi sehingga ular tangga berukuran raksasa. Untuk itu memainkannya bukan dengan menggerakkan pion melainkan pemain merupakan pion tersebut dengan melangkah atau melompat pada ular tangga raksasa.

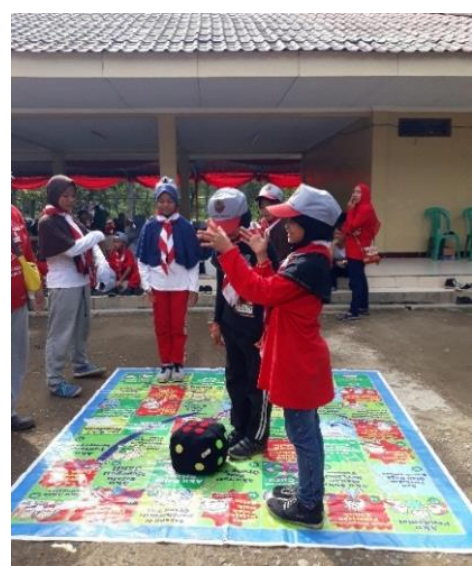

Gambar 3. Permainan Ular Tangga Raksasa (Sumber: Dokumentasi Pribadi)

Papan permainan terbuat dari spanduk yang telah dikreasikan dengan tema tertentu dengan ukuran $3 \times 3 \mathrm{~m}$. Terdapat 49 kotak di dalamnya, dengan gambar serta pesan-pesan yang baik dan buruk. Pesan yang baik maka akan naik, sebaliknya pesan yang buruk bisa jauh turun ke belakang. Pemain yang sampai terlebih dahulu pada nomor terakhir maka ia adalah pemenangnya.

\section{Permainan Layangan}

Ada berbagai macam bentuk layangan berdasarkan bahan yaitu don delundung, don nangka, daun nangka, don dapdap (daun dapdap), din teep, don teges (daun kayu jati) don kutat. Untuk memainkannya 
daun tersebut diberi ekor alang-alang, tali tambang untuk mengikat talinya dan sebagai sayapnya ditusuk dengan tangkai alang-alang. Layangan ini biasanya hanya dilarikan saja, tak mungkin bisa terbang tinggi karena talinya hanya beberapa meter saja. Ada pula dikaitkan di ujung galah, dimana galah tersebut ditancapkan ke tanah.
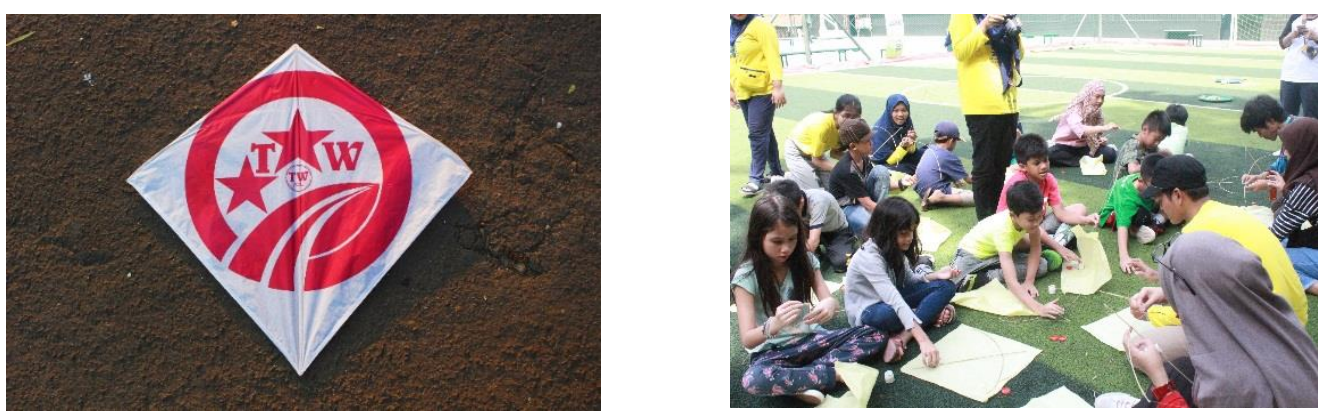

Gambar 4. Permainan Layangan (Sumber: Dokumentasi Komunitas TGR)

\section{Permainan Dampu Bulan}

Permainan ini tidak memerlukan biaya yang banyak, karena dapat di gambar dengan kapur di atas lapangan cukup dengan ukuran $2 \times 4$ meter bahkan 1x3 meter di jalan. Dan untuk gaconya cukup pecahan genting. Pesertanya 2 pemain, 3, 4 atau 6 pemain. Lebih dari itu dikhawatirkan permainan tidak berjalan dengan baik.

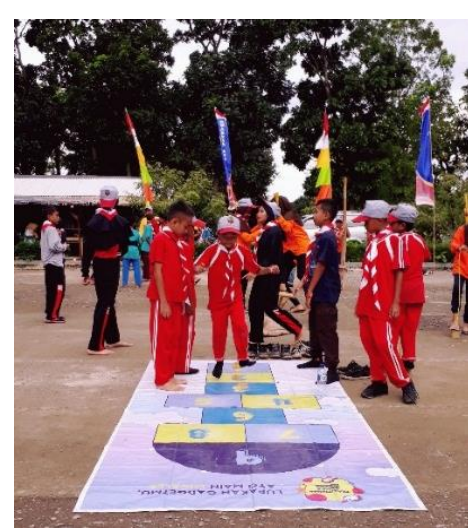

Gambar 5. Permainan Dampu Bulan (Sumber: Dokumentasi Pribadi)

Langkah-langkah dalam memainkan permainan dampu bulan adalah sebagai berikut.

a. Menerapkan aturan terlebih dahulul

1) Tidak diperbolehkan jongkok dengan tangan

2) Gacoan tidak melewati kotak/gambar yang telah dibuat

3) Menginjak gacoan lawan

4) Gacoan pecah artinya mati

b. Gambreng dan suten untuk menentukan urutan bermain.

c. A melempar gacoan ke ruang 1, kemudan sikap engklek (menggantung salah satu kakinya) menginjak ruang-ruang 2, 3, 4, 5,6, 7, 8, dan 9. Pada ruang 5,6 dan 8,9 dalam sikap obrog (kedua kakinya menginjak 
tanah), kemudian membalik dan kembali dalam sikap engklek pula. Ketika sampai pada ruang bercongklak dengan membalikkan badan sambil jongkok dan tetap menghadap belakang untuk mengambil gaco dan segera kembali ke tempat semula.

d. Kemudian melemparkan gaco ke ruang 2, angklek lagi seperti semula, kembalinya pada ruang 3 jongkok untuk mengambil gaco, menginjak ruang 1 kembali ke tempat semula. Demikian seterusnya.

e. Bila gaco dilempar lalu berhentinya tepat digaris, keluar ruang yang ditentukan, maka gugurlah ia. Kemudian bergantian bermain dengan pemain selanjutnya. Demikian seterusnya.

f. Bila gaco sudah dapat ditempatkan pada ruang 10, maka engklek mereka melalui ruang-ruang 1, 2, 3, 4, $5,6,7,8,9$, lalu keluar mengambil gaco dari sebelah atas dan kembalinya juga melalui ruang-ruang 9 , $8,7,6,5,4,3,2,1$, dan kemali ke tempat semula. Dengan ini pemain telah mendapatkan satu rumah.

g. Akhir permainan ditentukan dari jumlah rumah terbanyak, untuk yang kalah misalnya ada yang menggunakan hukuman kepada mereka yang paling kalah, misalnya digendong, atau diminta untuk cari benda yang disembunyikan. Tetapi ada juga yang bermain tanpa hukuman hanya untuk kesenangan dan kebersamaan.

\section{Bola Bekel}

Permainan bole bekel dimainkan antara dua atau empat orang di atas tanah yang keras atau lantai agar bola dapat memantul dengan baik. Para pemain duduk melingkar atau berhadapan dengan memberi jarak didepannya untuk ruang bermain, Alat yang digunakan adalah bola bekel berdiameter $3 \mathrm{~cm}$ atau $5 \mathrm{~cm}$ dan kulit kerang atau disebut biji dan biasanya berjumlah enam buah.

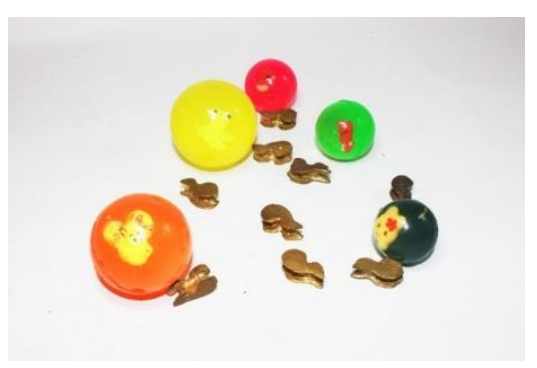

\section{Gambar 6. Permainan Bola Bekel (Sumber: Dokumentasi TGR Store)}

Langkah-langkah dalam memainkan permainan bekel adalah sebagai berikut:

a. Bola bekel dan biji bekel digenggam lalu biji bekel dilemparkan ke lantai selepas bola dilemparkan.

b. Awalnya biji bekel diambil satu persatu dan biji terkahir dengan cepat dilemparkan berbarengan. Selanjutnya diambil dua-dua, dan terus bertambah hingga jumlah keseluruhan

c. Setelah pengambilan satu-satu hingga jumlah keseluruhan, berikutnya adalah mengubah semua biji bekel menjadi bentuk pit dan diambil satu-satu seperti sebelumnya dan meningkat hingga jumlah keseluruhan.

d. Selanjutnya biji diubah menjadi bentuk rho, diambil satu satu-satu seperti sebelumnya dan meningkat hingga jumlah keseluruhan. 
e. Ketika tahapan-tahapan tersebut telah dilakukan maka tahapan berikutnya adalah ngaspel. Pada tahap ini sedikit berbeda, diawali dengan membentuk biji bekel menjadi barisan diawali pit yang sejajar, kemudian diubah menjadi rho,

f. Setelah itu, semua harus dilalui dengan melintasi melalui jari jempol dan telunjuk berbentuk U kebalik dan tak lupa memantulkan bola bekel.

g. Setelah selesai semua biji diambil dan membentuk tandatangan sebelum bola jatuh ke lantai.

h. Ketika semua tahapan ini sudah dilalui berarti si pemain telah melalui satu rangkaian dan menang.

\section{Eksplorasi Etnomatematika Dalam Permainan Tradisional}

\section{Unsur Matematika Pada Permainan Patok Lele.}

Permainan patok lele membutuhkan alat berupa kayu dengan bentuk tabung yang merupakan geometri ruang. Dimana alat tersebut berperan sebagi induk dan anak lele. Kedua kayu ini memiliki ukuran yang berbeda, dan jika melikat aplikasi matematika bahwa perbedaan ukuran ini memperlihatkan konsep perbandingan. Untuk alur permainannya dimana tiap satuan induk patok lele, pemain memperoleh total poin sesuai dengan kesepakatan yang dibuat. Langkah ini merupakan aplikasi dari perkalian sebagai penjumlahan berulang yang dilakukan oleh anak.
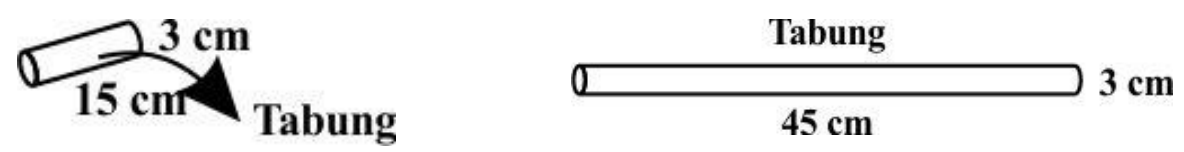

Gambar 7. Ilustrasi Alat Permainan Patok Lele (Sumber: Dokumentasi Pribadi)

Selanjutnya pada tahap anak membuat antara lubang dengan garis mulai terdapat jarak sejauh 1,5 m dimana jarak dalam geometri diberi arti jelas. Kata jarak selalu dikaitkan dengan hubungan letak dari dua benda. Dalam geometri benda-benda dipandang secara umum sebagai himpunan titik-titik tertentu, misalnya berupa sebuah titik, ruas garis, garis, bidang atau bangunan geometri yang lain.

\section{Unsur Matematika Pada Permainan Gundu}

Gundu dengan bentuk bola dengan ukuran $1 / 2$ inchi $(1.25 \mathrm{~cm})$ dimana jari-jarinya $0.625 \mathrm{~cm}$ sudah menunjukkan bahwa gundu memiliki unsur matematika.

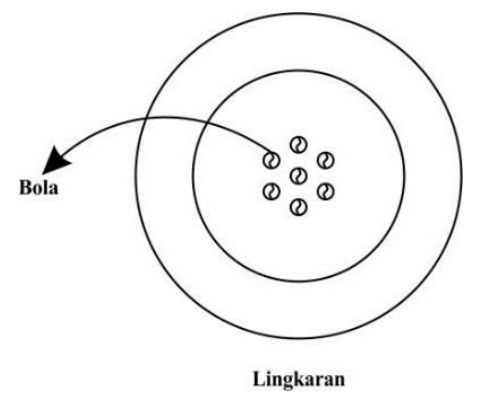

Gambar 7. Ilustrasi Lukisan Lingkaran Permainan Gundu (Sumber: Dokumen Pribadi)

Diawal permainan anak membuat jarak (batas) antara pemain dengan gundu dalam lingkaran, di 
dalamnya terdapat jarak antar garis yang memerlukan satuan panjang. Selain itu dalam permainan ini ada unsur operasi pengurangan untuk bilangan bulat yaitu ketika pemain berhasil menjentik gundu hingga keluar dari lingkaran, artinya mengurangi jumlah gundu dalam lingkaran dengan gundu yang berhasil dikeluarkan dari lingkaran. Setelah gundu dalam lingkaran habis maka para pemain menghitung jumlah gundu, artinya terjadi proses menghitung.

\section{Unsur Matematika Pada Pada Permainan Congklak.}

Anak memainkan congklak berkaitan erat dengan dunia sekitar karena penerapan hubungan bilangan dalam dunia nyata menandai awal masuk akalnya dunia nyata secara matematis. Permainan congklak adalah permainan tradisional yg menggunakan satu bilah kayu dengan 14 lubang kecil berukuran sama pada bagian kanan dan kirinya, dan dua lubang besar diujung kanan dan kiri. 14 lubang kecil, dibagi menjadi 2 bagian dengan 7 baris lubang pada kanan-kirinya, tiap-tiap lubang pada bilah kayu ini diisi oleh 7 buah biji (sejenis rumah kerang yg sudah tidak ada isinya lagi). Para pemain memasukkan biji ke dalam lubang biji, terjadi proses menghitung.

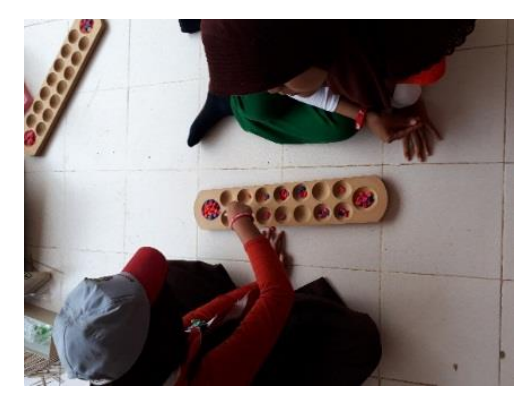

Gambar 8. Permainan Congklak (Sumber: Dokumentasi Pribadi)

Menghitung melibatkan paling tidak dua kemampuan yang berbeda. Pertama, anak harus dapat mengasilkan data standar dari menghitung dengan angka dengan urutan: "satu, dua, tiga empat ... dst." Kedua, pemain harus dapat menghubungkan urutan ini dengan cara satu demi satu pada himpunan yang dihitung. Masing-masing harus satu dan dihitung hanya satu kali. Selain membantu pemain mengenal bilangan-bilangan asli, pemain dapat berlatih meningkatkan kemampuan berhitungnya ketika hendak memastikan kembali jumlah biji tiap lubang pada papan congklak.

\section{Unsur Matematika Pada Permainan Ular Tangga}

Unsur matematika yang terdapat dalam permainan adalah papan permainan yang terbuat dari spanduk dengan ukuran $3 \mathrm{~m} \times 3 \mathrm{~m}$ berbentuk bangun datar persegi. Isi spanduk tersebut terdapat bentuk persegi sebanyak 49 buah dengan ukuran $40 \mathrm{~cm}$ x $40 \mathrm{~cm}$ ). Dimana para pemain melewati persegi-persegi tersebut sampai persegi terakhir. Dalam permainan ular tangga raksasa, pemain harus melemparkan dadu kemudian bergerak sebanyak bilangan yang ditunjukkan oleh dadu. Ketika pemain berdiri pada tangga, maka pemain "melompat naik" ke ujung tangga. Tetapi ketika pemain jatuh pada ekor ular, maka pemain harus "meluncur turun" ke persegi yang memuat kepala ular. Pemenang adalah pemain yang lebih dulu mencapai persegi kemenangan. 


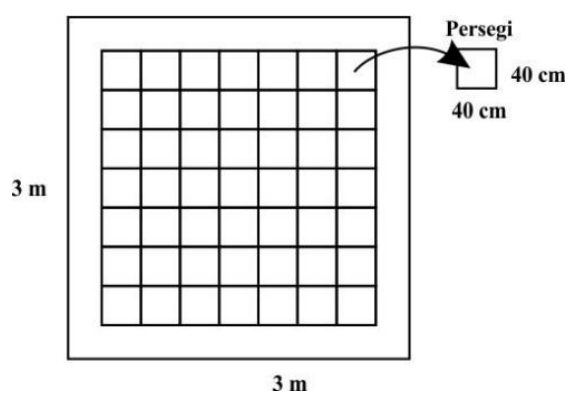

Gambar 9. Ilustrasi Alat Permainan Ular Tangga Raksasa (Sumber: Dokumen Pribadi)

Unsur matematika yang termuat dalam permainan ular tangga adalah membilang, penjumlahan, pengurangan dan peluang. Konsep membilang akan muncul ketika pemain melangkahkan kainya satu kotak demi satu kotak. Konsep penjumlahan akan muncul ketika pemain tidak melangkahkan diri per kotak, melainkan langsung menjumlahkan bilangan dadu dengan bilangan pada kotak posisi sebelumnya dan pada saat pemain membahas berapa banyak keuntungan yang mereka dapatkan ketika mereka mendapatkan sebuah tangga. Konsep pengurangan dapat ditegaskan ketika pemain ditanya seberapa banyak kerugian yang mereka tanggung ketika bertemu ular. Dari unsur matematika tersebut, kita tahu bahwa permainan ditentukan oleh peluang mata dadu yang muncul. Misalkan ketika pion sudah berada di kotak ke-45, tentu dibutuhkan munculnya mata dadu 4. Untuk mengetahui berapa peluang muncul mata dadu 4 , kita perlu tahu berapa banyak ruang sampel dari dadu dan peluang dari suatu kejadian.

Ruang sampel biasanya dilambangkan dengan S. Kejadian adalah himpunan dari ruang sampel, sedangkan titik sampel adalah setiap hasil yang mungkin terjadi pada suatu percobaan dengan ruang sampel $\mathrm{S}$, di mana setiap titik sampelnya mempunyai kemungkinan yang sama untuk muncul, maka peluang dari suatu kejadian A ditulis sebagai berikut:

$\mathrm{P}(\mathrm{A})=\mathrm{n}(\mathrm{A}) / \mathrm{n}(\mathrm{S})$

Keterangan:

$\mathrm{P}(\mathrm{A})=$ peluang kejadian $\mathrm{A}$

$\mathrm{n}(\mathrm{A})=$ banyaknya anggota $\mathrm{A}$

$\mathrm{n}(\mathrm{S})$ = banyaknya anggota ruang sampel $\mathrm{S}$

\section{Unsur Matematika Pada Permainan Layangan}

Bentuk permainannya sudah menunjukkan bahwa permainan layangan memiliki unsur matematika yaitu bangun datar layan-layang. Dengan membuat soal matematika yang menggunakan konsep trigonometri dengan contoh benang yang mengikat layangan sebagai hipotenusa atau garis miring tingginya yang dapat dicari jika jarak titik pangkal benang ke bawah layangan tersebutnya diketahui. 


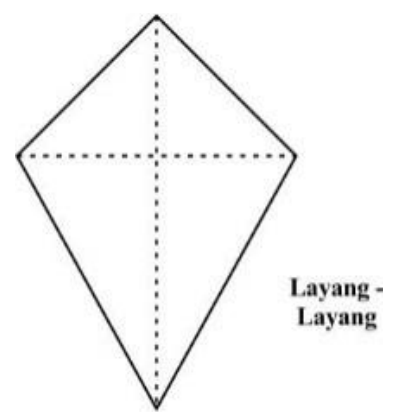

Gambar 10. Ilustrasi Alat Permainan Layangan (Sumber: Dokumen Pribadi)

Layang-layang merupakan bangun geometri datar yang dibentuk dari dua segitiga sama kaki yang alasnya sama panjang dan berimpit. Sifat layang-layang yaitu : a) sepasang-pasang sisinya sama panjang $(\mathrm{AB}=\mathrm{AD}, \mathrm{BC}=\mathrm{DC}) \mathrm{b})$ diagonalnya saling berpotongan tegak lurus $\mathrm{c})$ diagonalnya berpotongan dengan membagi dua sama panjang diagonal pendek $(\mathrm{BE}=\mathrm{DE}) \mathrm{d})$ salah satu diagonalnya merupakan sumbu simetri (AC). Dari sifat-sifat tersebut kita dapat mendefinisikan sebagai berikut. Layang-layang adalah sepasangsepasang sisinya sama panjang dan diagonalnya saling berpotongan tegak lurus, salah satu diagonalnya membagi dua sama panjang dan sebagai sumbu simetri.

\section{Unsur Matematika Pada Permainan Dampu Bulan}

Pada permainan dampu bulan terdapat unsur matematika yaitu berupa bentuk bangun datar yang dijadikan sebagai alat permainan dimana pemain membuat pola dampu bulan dengan berbagai bangun datar seperti persegi, persegi panjang, setengah lingkaran serta mengenalkan konsep dasar seperti angka. Permainan dampu bulan yang dimainkan anak, pada akhir permainannya, pemain menghitung dan menyebutkan banyak rumah yang diperoleh setiap pemain dan dibandingkan (lebih banyak atau lebih sedikit). Pemain X memperoleh 2 rumah,pemain $\mathrm{Y}$ memperoleh 1 rumah, dan pemain $\mathrm{Z}$ memperoleh 5 rumah. Pemenang permainan dampu bulan dalah yang paling banyak mendapatkan rumah yang paling banyak.

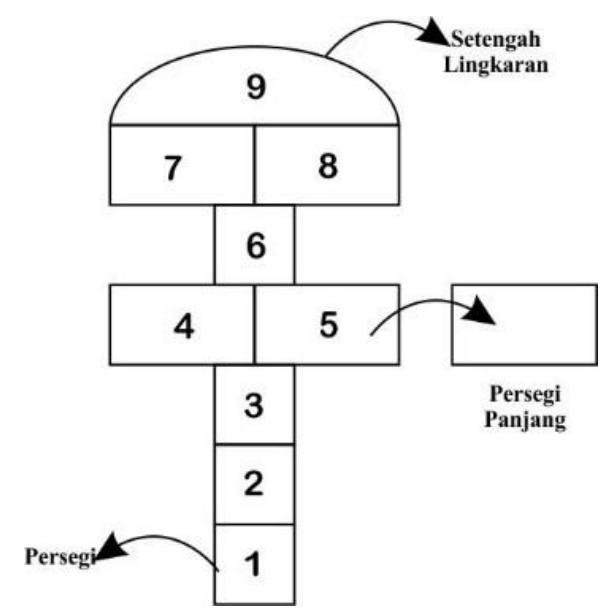

Gambar 11. Ilustrasi Alat Permainan Bekel (Sumber: Dokumentasi Pribadi) 


\section{Unsur Matematika Pada Permainan Bekel.}

Alat permainan bekel adalah bola bekel dan biji bekel. Bola bekel dengan bentuk bola dengan ukuran diameter $3 \mathrm{~cm}$ dan $5 \mathrm{~cm}$ sudah menunjukkan bahwa gundu memiliki unsur matematika.

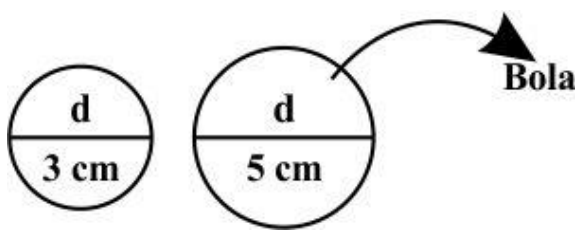

Gambar 12. Ilustrasi Alat Permainan Bekel (Sumber: Dokumentasi Pribadi)

Di awal permainan, setiap pemain mengetahui berapa banyak biji bekel yang digunakan sebagai alat permainan. Jika terdapat 6 biji bekel, maka setiap kali pemain mengambil biji bekel dilantai, pemain juga menghitung 1, 2, 3, 4, 5, 6 yaitu sudah berapa kali pemain melakukan pengambilan, serta menghitung biji bekel yang diambil saat melakukan pengambilan. Artinya terdapat konsep menghitung yang merupakan bagian dari komponen mengenai konsep bilangan, lambang bilangan atau angka. Saat pemain mengambil satu persatu biji bekel maka proses penjumlahan terjadi di tangan pemain.

Pemain juga dapat mengambil dua biji bekel dalam setiap pengambilan; artinya terdapat proses penjumlahan 2 biji bekel ditambah 2 biji bekel ditambah 2 biji bekel menjadi 6 biji bekel.

$1+1+1+1+1+1=6$

$2+2+2=6$

$3+3=6$

Setiap kali pemain mengambil satu persatu atau dua-dua biji bekel maka proses pengurangan terjadi di lantai yaitu enam di ambil satu, diambil satu, diambil satu jadi sisa tiga biji bekel.

$6-1-1-1=3$ atau $6-3=3$

$6-2-2-2=0$ atau $6-6=0$

Selain itu setiap kali pemain mengambil satu persatu biji bekel maka proses perkalian terjadi di tangan, yaitu banyaknya biji bekel setiap pengambilan dikali banyaknya proses pengambilan. Satu biji bekel pada pengambilan pertama, satu lagi biji bekel pada pengambilan ke 2, satu lagi biji bekel pada pengambilan ketiga, jadi ditangan terdapat 3 biji bekel dari tiga kali pengambilan. 3 × $2=6$ "Artinya 2 biji bekel diambil tanpa pengembalian, dilakukan 3 kali pengambilan, sehingga didapat 6 biji bekel yang sudah terambil. Dapat juga dikatakan 3 bekel diambil tanpa pengembalian, dilakukan 2 kali pengambilan, sehingga didapat 6 biji bekel yang sudah terambil."

$3 \times 2=2+2+2=6$ atau $3 \times 2=3+3=6$

Termasuk saat proses pembagian terjadi di lantai yaitu jika terdapat sepuluh biji bekel dilantai akan diambil dengan cara tiga biji bekel pada setiap kali melakukan pengambilan. Ambil tiga biji bekel pada pengambilan pertama, tiga lagi biji bekel pada pengambilan kedua, Artinya enam biji bekel dibagi tiga biji bekel disetiap pengambilan, sama dengan atau terjadi dua kali pengambilan. 
$6: 3=2$ (artinya terdapat 6 biji bekel, diambil 3 biji pada setiap pengambilan tanpa pengembalian, sehingga didapatkan 2 kali pengambilan). $6: 2=3$ (artinya terdapat 6 buah biji bekel, diambil dua biji pada setiap pengambilan tanpa pengembalian, sehingga didapatkan 3 kali pengambilan).

Dengan begitu maka berhitung sangat dekat dengan kehidupan sehari-hari di sekitar tempat tinggal, sekolah, tempat umum dan di mana saja salah satunya adalah bermain permainan bekel. Dan behitung merupakan tahapan yang harus dilalui oleh anak. Oleh karena itu, pembelajaran berhitung dimulai sejak usia dini sangat disarankan.

\section{Pembahasan}

Anak kecil mengembangkan pembawaan matematika sejak pengalaman mereka di usia dini. Dalam hal ini, tentunya kesempatan dalam belajar seharusnya dibawa secara positif dan lebih mendukung aktivitasnya. Dasar matematis salah satunya dapat tertanam saat mereka melakukan permainan tradisional Indonesia. Adapun aktivitas yang digunakan dalam tahapan permainan tradisional, seperti aktivitas membilang dan menghitung, aktivitas mengukur, aktivitas mendesain, dan aktivitas mengenal bangun ruang serta bangun datar.

Dalam aktivitas yang pertama adalah membilang dan menghitung dimana pemain menggunakan bilangan untuk menghitung. (Hasanah \& Pratiwi, 2017) menjelaskan bahwa permainan tradisional bermanfaat untuk mengenalkan konsep dasar seperti angka. Seperti dalam permainan gundu, pemain menghitung jumlah gundu yang akan digunakan dalam bermain. Pada permainan patok lele, pemain menghitung jumlah poin yang didapat. Lalu ada juga pada permainan congklak, pemain menghitung banyaknya biji dalam rumah. Selain itu pada permainan ular tangga raksasa, pemain membilang angka yang didapat dari dadu yang dilemparkan, dan juga melakukan perhitungan pada langkah kaki. Untuk permainan dampu bulan, pemain menghitung jumlah rumah dan mengenali, serta membilang anak pada setiap engklek dan obrog kaki. Hal yang sama juga terjadi pada permainan bekel, yang mana pemain menghitung biji bekel yang diambil selama permainan berlangsung. Sejalan dengan temuan penelitian (Susanti, 2020) menjelaskan bahwa aktivitas membilang dan menghitung pada permainan tradisional secara tidak langsung mendukung perkembangan kognitif siswa dalam belajar matematika secara tematik. Dengan bermain, secara tidak langsung anak telah terhubung dengan angka-angka di pikirannya untuk menjalankan operasi bilangan.

Ativitas yang kedua adalah mengukur, yang merupakan kegiatan membandingkan suatu besaran yang diukur dengan besaran sejenis yang dipakai sebagai satuan. Seperti pada permainan patok lele dimana pemain menggunakan alat ukur tidak baku seperti menggunakan induk patok lele untuk mengukur jarak antara lubang dengan garis batas pemain. Selain itu, dalam permainan gundu, anak melakukan pengukuran untuk menghitung jarak antara gundu dan lingkaran dengan menggunaan jengkal lengan. (Pratiwi \& Pujiastuti, 2020) dalam temuan penelitiannya menjelaskan bahwa kegiatan mengukur seperti ini secara tidak langsung dapat melatih anak untuk menghitung suatu jarak. Dari sini, mempelajari matematika khususnya konsep mengukur terlihat lebih nyata dan tentunya membuat anak lebih bersemangat dalam belajar. 
Aktivitas yang ketiga adalah aktivitas mendesain, dilihat dari aktivitas merencanakan sampai pelaksanaannya. Dalam konteks ini anak-anak mulai belajar memenuhi aturan yang mereka buat sendiri. Maka dari itu aturan permainan tiap daerah terkadang berbeda-beda. Pada intinya permainan dibangun secara bersama-sama demi menjaga permainan dapat berlangsung secara wajar. (Aprilia et al., 2019) dalam temuannya mengungkapkan secara tersirat bahwa aturan yang dibuat dalam suatu permainan, secara tidak langsung mengajarkan anak untuk memahami konsep logika matematika. Sebagai contoh, bila aturan dalam permainan dilanggar, maka ada konsekuensi bagi yang melanggarnya. Dari sini anak menjadi terstimulus untuk mengembangkan kemampuan berpikir kritisnya.

Aktivitas terakhir adalah mengenal bangun datar dan bangun ruang. Untuk bangun datar, dapat dilihat pada permainan gundu, seperti membuat pola lingkaran. Selain itu, kita juga dapat melihat pola yang terbentuk pada permainan dampu bulan, seperti persegi, persegi panjang dan setengah lingkaran. Bentuk persegi juga terdapat pada permainan ular tangga rakasa. Bangun datar dapat juga ditemukan pada layanglayang. Sementara untuk bangun ruang, dapat kita temukan pada bola bekel dan gundu. Ada lagi alat permainan patok lele yang berbentuk tabung. Sejalan dengan penelitian (Dhiki, 2019) memaparkan bahwa pembelajaran matematika dengan menggunakan benda dapat memperkaya aplikasi matematika yang ada di sekitar anak, sehingga memfasilitasi anak untuk memahami matematika yang bersifat abstrak menjadi lebih konkret. Dengan demikian, melalui objek permainan tradisional anak dapat memahami matematika dengan mudah dan menyenangkan.

\section{KESIMPULAN}

Dari hasil analisis maka diperoleh simpulan, dengan penjelasannya sebagai berikut:

1. Permainan tradisional patok lele mengandung unsur satuan panjang, mengenal bangun ruang tabung, dan menghitung skor mencakup operasi penjumlahan, perkalian, pengurangan dan pembagian.

2. Permainan tradisional gundu mengandung unsur bangun ruang bola, bangun datar lingkaran, operasi pengurangan, dan membuat pola lingkaran

3. Permainan tradisional congklak mengandung unusur operasi hitung dan urutan bilangan.

4. Permainan tradisional ular tangga raksasa mengandung unsur bilangan, operasi hitung dan peluang.

5. Permainan tradisional layangan mengandung unsur bangun datar layang-layang.

6. Permainan tardisional dampu bulan mengandung unsur membuat pola, bangun datar persegi, persegi panjang dan setengah lingkaran, dan operasi hitung.

7. Permainan tradisional bekel mengandung unsur bangun ruang bola dan operasi hitung.

Berdasarkan simpulan dan implikasi maka peneliti mengajukan saran-saran sebagai berikut. (1) Bagi guru, dapat menggunakan etnomatematika permainan tradisional dalam pembuatan desain pembelajaran. (2) Bagi perguruan tingi yang menghasilkan guru pendidikan matematika, pendidikan jasmani rohani dan kesehatan, diharapkan membekali para calon guru untuk mempelajari permainan tradisional sejak awal agar para calon guru tersebut mampu menerapkannya saat mengajar. (3) Bagi masyarakat, upaya pelestarian permainan tradisional Indonesia merupakan tanggung jawab kita bersama 
Eksplorasi EtnomatematikaPada Permainan Tradisional Indonesia Komunitas TGR (Traditional Games Return), Citra Demi Karina, Supardi U.S, Suparman, I.A

baik di lingkungan pendidikan atau sekolah maupun di lingkungan masyarakat luas.

\section{UCAPAN TERIMA KASIH}

Terima kasih kami ucapkan kepada Komunitas Traditional Games Returns, semakin terasa manfaatnya untuk masyarakat. Terima kasih juga kepada ayah, ibu, kakak, adik, dan suami tercinta atas dukungan yang telah diberikan.

\section{REFERENSI}

Aprilia, E. D., Trapsilasiwi, D., \& Setiawan, T. B. (2019). Etnomatematika pada Permainan Tradisional Engklek Beserta Alatnya sebagai Bahan Ajar. Kadikma, 10(1), 85-94. https://doi.org/10.19184/kdma.v10i1.11735

Arikunto, S. (2002). Prosedur penelitian. PT. Rieke Cipta.

Dharmamulya, S. (2008). Permainan Tradisional Jawa. Kepel Presss.

Dhiki, Y. Y. (2019). Etnomatematika: Aplikasi Bangun Datar dan Bangun Ruang pada Alat Musik Tradisional Wolotopo Kabupaten Ende. Jurnal Dinamika Sains, 3(1), 92-95. https://doi.org/10.37478/optika.v3i1.120

Emzir. (2012). Metodologi Penelitian Kualitatif: Analisis Data. Rajawali Pers.

Ghony, D. M., \& Almanshur, F. (2014). Metodologi Penelitian Kualitatif. Ar-ruzz Media.

Hasanah, \& Pratiwi, H. (2017). Pengembangan Anak Melalui Permainan Tradisional. Aswaja Presindo.

Mulyani, N. (2016). Superasyik Permainan Tradisional Anak Indonesia. Diva Press.

Pratiwi, J. W., \& Pujiastuti, H. (2020). Eksplorasi Etnomatematika pada Permainan Tradisional Kelereng. Jurnal Pendidikan Matematika Raflesia, $\quad 5(2), \quad 1-12$. https://ejournal.unib.ac.id/index.php/jpmr/article/view/11405

Sugiyono. (2008). Memahami Penelitian Kualitatif. Alfabeta.

Susanti, E. (2020). Eksplorasi Etnomatematika Konsep Operasi Hitung dalam Permainan Tradisional Kempreng. Suska Journal of Mathematics Education, 6(1), 1-8. http://ejournal.uinsuska.ac.id/index.php/SJME/article/view/10025 